\title{
International organisations and the role of collective bargaining ${ }^{1}$
}

\author{
Roberto Pedersini, Università degli Studi di Milano
}

\begin{abstract}
Summary
The article analyses the position of international organisations devoted to economic and employment issues on the role of collective bargaining. The article develops a stylized framework to analyse the functioning of international organisations, which focuses on their mission and basic expert knowledge, their structure with a political and a technical level, and the relationship with the external environment, where the political constituencies and the expert communities have a prominent role. Such analytical framework represents a two-fold tool: on one side, it helps distinguish between different organisations on the basis of their missions and expert knowledge; on the other, it provides an indication of the dynamic factors in the analyses and actions of international organisations. The possible sources of transformation in the position of international organisations are found in the limited effectiveness of past policy recommendations (a technical and evidence-based check) and in the growing political pressures of specific demands (a political and consensus-based development). The article then provides an exploratory analysis of the positions of the international organisations under review to conclude that most of international organisations remain anchored to their missions and established mainstream economics analyses, with the partial exception of the OECD and the notable distinction of ILO. After pointing to the quite different nature of the European Commission, as part of a fullfledge polity, the article concludes that the emerging more nuanced position on the role of industrial relations and collective bargaining among international organisations includes some important elements. In particular, the recognition of its potential for social inclusion and cohesion may support the introduction of promotional measures, in lieu of the mostly corrective interventions of the recent past.
\end{abstract}

Keywords: industrial relations, collective bargaining, international organisations, global governance, public policies

Industrial relations and collective bargaining institutions play a significant role in the regulation of the labour market and they also represent a relevant component of democratic systems, since they actualise the principle of interest and associational representation. Such two-fold relevance of industrial relations, economic and political at the same time, provides different and possibly contrasting premises and points of view for their assessment as well as for the identification of the specific arrangements that are mostly desirable. With a certain degree of simplification, it is possible to distinguish at least three levels for such evaluation: the processes, the output, and the outcomes. If industrial relations are a private law- or rule-making system (Dunlop 1993), then it appears that the first point of observation will consider the capacity to provide representation, voice and participation rights; the second will focus on the level and appropriateness of protections, prerogatives and rights; the third will assess distributive effects and economic incentives as well as the impact on efficiency and employment and unemployment levels. In terms of scholarship, political science would be closer to the first point of observation, labour law to the second and economists to the third one. Sociologists, the group I belong to, would try to take all of them into consideration. In addition, the political relevance of industrial relations means that value-based orientations may affect the level of support it enjoys in the public debate and in policy circles, depending on the contingent positions and priorities which prevail in the political landscape.

Why are these considerations relevant for the objective of this article? Because international organisations are quite a composite group of entities and they remarkably differ in terms of focus and missions. As intergovernmental organisations and specialised agencies, they usually include a political and a technical level and they often cater for single issues. The combination of their scope and mission defines the type of technical knowledge that informs their analyses and actions. In

\footnotetext{
${ }^{1}$ Accepted Manuscript published as Pedersini, R. (2019), International organisations and the role of collective bargaining, Transfer: European Review of Labour and Research, 25(2), 181-203. C The Author(s) 2019. https://doi.org/10.1177/1024258919853063.
} 
practice, this means that each organisation considers collective bargaining and industrial relations from a specific point of view and can especially value some of the dimensions mentioned above, political participation, legal rights, economic efficiency. Indeed, in some cases, the interest in industrial relations may be incidental and the impact of the organisation's activities on industrial relations rather indirect, although it could nevertheless be significant.

In sum, we should expect the actions of intergovernmental organisations to be framed by their institutional mission, the disciplinary knowledge of their staff, and the political consensus or conflict among their members regarding the priorities to be pursued in specific periods, which may change depending on the political agenda. For these reasons, the positions and actions of international organisations may reflect the political 'spirit of the times', the established practices of their officers as well as the advancements in their technical knowledge.

Having clarified this general framework, the purpose of this article is assessing whether and to what extent it is possible to maintain that the views of international organisations have lately changed regarding the role of collective bargaining and industrial relations. The question has become relevant because in recent times a number of international organisations, quite different for their nature, responsibilities and entitlements, have expressed views which seem to reverse previous positions or restore a more favourable stance towards collective bargaining. In particular, organisations that had been widely criticised by the trade unions for their disregard of the positive role played by worker representation and collective bargaining (see for instance ITUC 2013 on the IMF policy recommendations) have apparently started to consider the collective regulation of employment relations in a new, more positive light. The OECD with the new Jobs Strategy (2018), the European Commission with the new start for social dialogue (2015) and the European Pillar of Social Rights (2017), even the IMF with the consideration of wage bargaining as a means to promote growth appear to concede a new role to collective bargaining (2016). Does the impression of a change in attitudes correspond to more substantial evidence?

Answering our question will entail an assessment of the degree of support for collective bargaining expressed by different international organisations as well as the specific features or components of the industrial relations and collective bargaining systems which they regard as relevant. As already underlined, we should not expect that all international organisations are concerned with collective bargaining and that they represent a unitary block, rather the opposite. Therefore, these notes will present a general analysis, which will focus mainly on the most relevant organisations in the field of economic and employment issues. Moreover, providing a detailed analysis of the positions and actions of individual organisations is beyond the objectives of this article. Other articles in this issue are devoted to this kind of study and readers can find there further information and details.

In this general overview, the first section briefly presents the range and specificities of the international organisations that are considered in this analysis and how we can identify 'their positions'. The second section provides a general presentation of the elements that may influence the current views on collective bargaining of the various international organisations and the possible changes compared to previous periods. The third section includes a discussion of these positions, as they emerge from official documents and statements. The concluding section provides a response to the question: has anything changed?

\section{Goals, case selection, method, data}

The first objective of this article is to propose an analytical framework for assessing the positions of international organisations on collective bargaining, and industrial relations, for what matters. The starting assumption is that we cannot consider international organisations as homogeneous 
entities. They have different institutional missions, they rely on different specialist knowledge, they operate in different manners. This means that they will develop distinct viewpoints on collective bargaining. In fact, collective bargaining may occupy a key or a marginal position in their institutional domain and this will be reflected in the amount of resources devoted to the study and consideration of collective bargaining processes and outcomes as well as in the depth and detail of their analyses. The second objective is the identification of the position of the various international organisations under review about the potential of collective bargaining in terms of the three dimensions outlined above: political participation, labour rights, economic performance (basically growth and equality) and whether such potential depends on specific collective bargaining agreements. Therefore, we are interested in summarising, as far as possible, their diagnoses and prescriptions. We expect that the type of organisation (mission, knowledge, operations) influences the viewpoint and in turn the assessment of both the potential and the desirable features of collective bargaining, for instance in terms of bargaining structure and institutional support it can receive from legislation.

The selection of cases does not aim to be exhaustive, but it intends to be as inclusive as possible. However, the detail of our analysis depends on the relevance that collective bargaining plays for the different international organisations. Therefore, although the main international organisations in the field of economic and employment issues are included, the analysis is more in-depth and clear in the case of entities whose missions comprise a specific focus on employment relations, because they are expected to allow for more meaningful analysis, with the specification of the role of collective bargaining. If there is no special consideration for the role and potential of collective bargaining, the tendency to replicate the standard views of the technical knowledge imbuing the organisation will be strong.

The selection of cases is therefore rather wide and includes the most prominent international organisations in the field of economic and employment issues. To start with, the three major Bretton Woods organisations shall be included: the International Monetary Fund (IMF), the International Bank for Reconstruction and Development (World Bank, WB), and the current World Trade Organisation (WTO, as the successor of the General Accord on Trade and Tariffs, GATT). Then, the two organisations which cover specifically employment issues, as the main or key topic: the International Labour Organisation (ILO, with the International Labour Office as its secretariat) and the Organisation for Economic Cooperation and Development (OECD). Finally, the European Commission (EC) is also included to take into consideration the debate over the role that the European Governance is playing in the field of industrial relations (Marginson 2014; Marginson and Welz 2014; Van Gyes and Schulten 2015).

As an exploratory analysis, our assessment is based on the information and statements included in the official documents produced by the international organisations. From a practical viewpoint, understanding the stance of an international organisation on a specific issue as well as identifying the changes of its positions over time require to distinguish between different levels of analysis. As in the case of all corporate actors, complex organisations are made of various roles and offices, with specific responsibilities and objectives (Coleman 1990, pp. 421-450). The plurality of 'natural' actors and organisational sections and segments make it difficult to identify 'the' corporate position. This means that we have to decide where to locate our observation point, in order to avoid to be distracted or misled by the 'noise' produced by the various voices and positions which contribute to shape the organisational stance. In practice, it may be quite challenging to identify one unitary positions, as internal conflicts might remain unresolved and this could be reflected in the presence of contradictions and a certain indetermination in the organisation's position, which may include different coexisting views. 
The risk of misrepresenting the position of the corporate actor is particularly high in the case of international organisations, which usually support debates over contested issues and whose objectives include promoting evidence-based policy-making that depends on the advancement of knowledge in a specific field. The abundance of research papers (all of them with the disclaimer that they do not represent the organisation's view) produced or hosted by many of the international organisations under review here often provide the basis for various interpretations. Although they certainly represent ongoing discussions, we should not mistake the debate for the position.

The intergovernmental nature of these actors indicates that we may look for their 'true' positions in the official key documents or in the declarations produced by their peak governance bodies. The relevance of such political texts is utmost and cannot be denied. However, we have to take into consideration that these organisations act too, and their actions may be of greater importance for employment relations and collective bargaining. Their actions pertain essentially to the technical level and can be identified in their policy analyses and recommendations, and in their interactions with national authorities. This gives us three main types of documents: 1) the key statements produced by the political governance bodies; 2 ) the analysis included in the principal publications, usually as annual reports; 3 ) the policy analyses and recommendations released to provide guidance to actual policy-makers, usually national governments. Of these, the second ones are usually available and represent the main source for this article. When available, the third type of document, policy recommendations, are particularly illuminating and therefore are included in the analysis. Political statements, the first kind of document, may be rather general and need to be made operational. For this reason, they are not usually included, since we expect them to be reflected in the more technical materials. The only exceptions are two key political documents issues by the ILO (2019) and OECD (2018).

In terms of method, we will use a rather straightforward content analysis which aims to identify the following main elements:

- The criteria to assess collective bargaining, essentially by identifying whether it is mainly the capacity to ensure fair terms of employment and working conditions, workers' voice and participation, or economic efficiency and what kind of balance or trade-offs are identified between these three main criteria;

- The structure of collective bargaining which is regarded as more conducive to achieve a good 'performance' of collective bargaining according to the assessment criteria (single-employer or multi-employer, coordinated/organised or uncoordinated/disorganised);

- The institutional features which are considered as supportive of collective bargaining in the light of the same criteria, such as extension mechanism, trade union prerogatives, workers' representation bodies;

- The content of collective bargaining which is regarded as consistent with ensuring a good performance.

Not all of these may be included in the positions of the various organisations. As mentioned earlier, we expect that the more central are employment relations in the mission of the international organisations, the more detailed is the analysis of collective bargaining.

\section{Missions, technical knowledge, political priorities}

International organisations can be located at the intersection of political systems, administrative bodies, expert communities, and policy-making. If we concentrate our attention on the operations of their permanent departments and technical staff, we can consider them as providers of expert 
knowledge, administrative capacity and coordination resources to facilitate the achievement of the goals and missions identified by the intergovernmental treaties or conventions, which established them. In other words, they are stable bureaucracies set up to strengthen the implementation of international agreements (Ness and Brechin 1988; Muldoon 2004; Martin and Simmons 2012). In this, they basically rely on expert knowledge and they assist the governments by providing operational tools and analytical instruments to respond to the questions and provide solutions to the problems that fall within the remit of their respective institutional responsibilities. At the same time, if we consider instead the political dimension of international organisations - rather than the technical one - we should recognise that the ways in which questions and problems are addressed by the technical expertise may reflect political priorities and could include a political vision (Reinalda 2001; Joachim, Reinalda and Verbeek 2008).

In this sense, international organisations are neither purely political, nor purely technical entities. Although the agenda is largely set by the conventions which established them, the political and the technical levels shape its implementation. The technical secretariats are often presented and regarded as the expression of expert knowledge, but they cannot avoid to reflect the political zeitgeist. At the same time, they remain framed in the disciplinary boundaries of the expert knowledge they embody. This underlying tension in the relationship between the political and the technical dimensions as well as the developments that take place in each of them are the essential dynamic elements in the operations of international organisations.

The two groups of actors are tightly linked, with the political representatives (and the national governments in the end) having priority over the technical staff. However, the more technical the responsibility of the organisation, the more information asymmetry will characterise the relationship, with the possibility that the political representatives are 'captured' by the technical officers. The different stability of the two groups may also play in favour of technical experts, which may stay longer compared to the political representatives. Even though the connections between the political and the technical levels are tight, the two levels are to some extent independent, since political guidelines have to be translated into operational measures, and there is often some space for interpretation as well as a sort of resilience of practices. This means that deviations, anticipation and delay between the political declarations and the technical operations can and do take place, including for allowing the necessary coordination between the two levels.

For our purposes, it can be useful to sketch a simplified model of the decision-making, feedback and learning processes that take place within international organisations. This can help assess the possible reasons and significance of changes in the organisation's (political) positions and (technical) policies, which, as mentioned above, may at times diverge. Within each organisation, we can distinguish between the political level, made of representatives of member countries, and the technical level, composed of the bureaucracy, officers and technical experts who work in the organisation's secretariat and offices. Outside the organisation, we can similarly find different groups or actors: the constituencies of the governments represented in the organisations (voters, interest groups, associations, the public at large, etc.) and the expert communities, which are relevant for the specific and technical knowledge on which the missions and goals of the international organisation are based (Dellmuth and Tallberg 2015; Peters and Peter 2012).

Such external groups are quite important for the basic processes which involve the two internal groups: consensus, which is mainly relevant for the political level, and consistency, which is paramount for the technical level. In particular, the latter mean that the actions taken by the organisation must be consistent (and up-to-date) with the disciplinary knowledge which informs the responsibility and actions of the organisation. In this respect, it should be underlined that international organisations are usually required to guarantee political neutrality in their relationship 
with the national governments and authorities. Therefore, recommendations, actions, and possibly sanctions promoted by the organisations must be formally in line with the organisation's entitlements and substantially conform to the analyses and prescriptions of the best technical knowledge in the relevant field.

For the two groups, legitimation mostly derives from different sources and takes a distinct nature: political for governmental actors, and technical for the officers. Certainly, the two types of legitimation are intertwined, since the officers will depend on the political priorities set at the intergovernmental level, while the latter has to rely on the technical knowledge to achieve its goals. The relationship between the political level and the constituencies is mediated through the national governments, which influence the agenda of the international organisation, within the remit of its institutional mission. Therefore, the political representatives in the organisation are somehow insulated from the direct pressure of the interests and demands of the constituencies, as they directly respond to the national governments. Moreover, the intergovernmental nature of the organisation, dilutes the pressure of specific national interests and the presence of a specific institutional mission provides a possible protection from particularistic demands. The relative autonomy of the organisational environment from direct external pressure may reinforce the role of the technical staff, as long as the political level remains divided. So, it means that the political level can become particularly important in times of fundamental policy shifts, which involve the great majority of the political actors. In 'ordinary times', the technical staff (and their disciplinary perspectives) are likely to play a leading role in the organisation's operations.

\section{Figure 1. International organisation as collective actors. A simplified model}

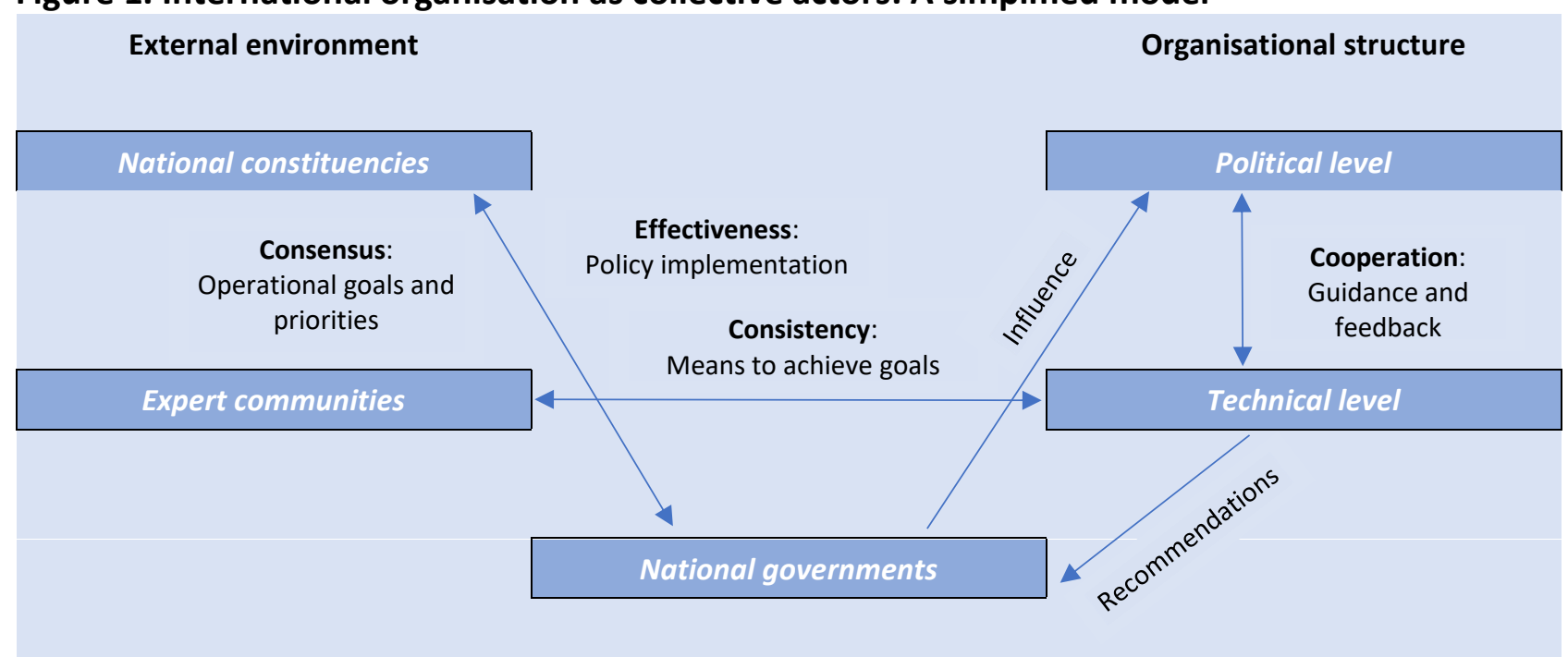

Within the organisation, the relationship between the political and the technical levels can be depicted as cooperative and based on guidance (from the political level to the technical one) and feedback (mostly from the technical level to the political one), with a view to coordinate the goals (set by the institutional mission and the political agenda) with the technical means (policies and tools) to achieve them. National governments receive the policy assistance and recommendations of international organisations and they are responsible for the implementation at national level. The effectiveness (and possibly the efficiency) of the implemented policies are the main criteria used to assess the operations of international organisations, by national constituencies and governments. The capacity to foster and maintain consensus about the recommended policies at national level feeds back into the political cycle of the organisational governance. Similarly, technical staff may take into consideration the measured effects of the policies or strategies pursued in the past and 
adjust them dynamically, in a trial-and-error fashion, in an open dialogue with their disciplinary communities.

Changes in the organisation's stance and positions can emerge from these two basic processes, the political one based on consensus and the technical one based on consistency. They constitute the main channels of organisational learning: the first refer essentially to the input phase (the problems that have to be addressed) and the second one to the output side (the policy responses supported by the organisation). The link is provided by the impact and effectiveness of the implemented policies on the problems to be addressed, as perceived and interpreted in the political and technical domains - which may offer different assessments.

These two processes tend to be adaptive and incremental. Especially the technical analyses remain framed in established theories and analytical schemes. More radical changes need a shift in perspectives, which happens only at particular junctures, often involving both the political and the technical dimensions. The perceived incapacity of existing theories or models to respond to pressing demands and the availability of alternative approaches can lead to the emergence of a 'new paradigm' (as in Thomas Kuhn's account of scientific revolutions, but including at a much lower scale). The growth of Keynesian economics in the 1930s and of monetarism in the 1970s may be associated to similar dynamics.

\section{Making sense of the international organisations' attitudes about collective bargaining}

The stylised model sketched above may oversimplify the relations and processes which involve international organisations. However, it can serve our purpose of identifying the emerging novelties in the stance of international organisations over the role of collective bargaining and, more generally, industrial relations. Our starting point can be the identification of the main features of the organisations under review (Table 1). Most of them focus on economic issues at the macro or micro level and use an economic perspective. Only the ILO approaches the issue of collective bargaining from the point of view of labour rights ensuring voice and protections. The European Commission, as part of a quite peculiar polity, embraces both the economic and labour rights standpoints. Therefore, comparing the positions of the ILO, IMF, World Bank and OECD can be misleading, if we do not frame our analysis by emphasising the differences in their scope, objectives and structures. Similarly, if we want to include the European Commission, we have to acknowledge the fundamental distinction between the former specialised agencies and a full-fledge political entity. Our analysis must consider the different roles they play and the fact that they operate at different levels and with quite distinctive instruments.

The international landscape is in fact populated by a growing number of organisations, offices and agencies, which are involved in the so-called global governance (Held and McGrew 2002). In this article, we take into consideration only a small fraction of them and we focus on those covering specifically economic and employment issues, with the addition of the European Commission. The selection is to some extent arbitrary, but it covers the most important international bodies in the field of economic and employment issues. Since the objective is not to provide a comprehensive nor a detailed analysis, reference to the major international organisations will serve us well.

Of particular relevance for our purpose are the respective missions, the key expert knowledge they are endowed with, and how they can exert influence on national politics and governments. The latter can vary considerably and can help us identify where our analysis should focus. For instance, the IMF is responsible to ensure macroeconomic stability and support the international payment system. Its actions are based on economic and financial expert knowledge. It operates mainly in the provision of credit to governments in order to address significant economic distress, under policy 
conditionality. The positions of the IMF over collective bargaining are therefore incorporated in the requests made to governments in financial difficulties and reflected in the commitments undertaken by governments to meet conditionality and included in the Memoranda of Understanding signed by the governments and the IMF. Moreover, the IMF regularly issues country analyses and recommendations. However, its mission does not include specifically collective bargaining and industrial relations. Quite different is the role of the ILO, established as a tripartite organisation in 1919, which can provide direct support to governments to design legislation concerning labour relations, including industrial relations and collective bargaining, as well as to social partners or labour-related civil society associations.

Depending on their specific missions, international organisations catering for economic issues may consider collective bargaining for its impact on macroeconomic stability, economic growth or microeconomic efficiency. Their attention is essentially on the wage-setting dimension of collective bargaining and less on the normative elements, except for those which may impact on firing costs. It is difficult to summarise a long and extensive literature on how collective bargaining can influence economic performance. However, as far as macroeconomic stability is concerned, the early debate about the benefits of wage moderation to tackle the economic instability of the 1970s and 1980s underlined the role of centralised collective bargaining, as part of neo-corporatist arrangements. However, according to the hump-shaped hypothesis of Calmfors and Driffill (1988), decentralised collective bargaining structures could perform equally well. Microeconomic efficiency, from a standard economic perspective, requires the alignment between wage developments and productivity trends, in order to sustain both cost competitiveness and employment - and ensure wage moderation by definition. The combination of these analyses would make decentralised collective bargaining more desirable from a standard economic perspective. Moreover, institutional support in terms of extension measure should be limited and supported by stringent representativeness criteria.

Less orthodox economic analyses consider the impact of collective bargaining for its potential for sustaining growth through demand - rather than competitiveness - and for reducing inequality (Lavoie and Stockhammer 2012; Baccaro and Howell 2017). From these viewpoints, inclusive collective bargaining structures would provide a better environment for economic growth and equality and institutional support would be advisable to reinforce the overall effects. With similar implications, at the micro-level, the constraints that a high-wage regime and job protections put on company strategies have supported the idea that 'beneficial constraints' can promote the upgrading of the production system and support the so-called 'high road' to competitiveness, made of high skills, high wages and high quality (Streeck 1997, Traxler, Kittel and Lengauer 1997). These views have not been (yet) incorporated in the common standard recommendations, but found some room in the analyses of some international organisations (see below).

The focus on labour rights and social cohesion shifts the attention to the inclusiveness and levels of protection as well as on their quality. Centralisation and coordination of collective bargaining provide a better basis for achieving such goals than decentralised bargaining. Ensuring participation and voice rights is part of the institutional mandate of some organisations.

Table 1. International organisations: missions, expert knowledge, influence

\begin{tabular}{|l|l|l|l|l|}
\hline Organisation & Type & Mission & Expert knowledge & Influence \\
\hline World Trade Organization & $\begin{array}{l}\text { International } \\
\text { organisation }\end{array}$ & $\begin{array}{l}\text { Promote the development of an } \\
\text { integrated, viable and durable } \\
\text { multilateral trading system }\end{array}$ & Economic, Trade & $\begin{array}{l}\text { Trade agreements, } \\
\text { dispute } \\
\text { settlement }\end{array}$ \\
\hline
\end{tabular}




\begin{tabular}{|c|c|c|c|c|}
\hline Organisation & Type & Mission & Expert knowledge & Influence \\
\hline World Bank Group & $\begin{array}{l}\text { International } \\
\text { organisations }\end{array}$ & $\begin{array}{l}\text { Economic development to end } \\
\text { poverty and boost prosperity for } \\
\text { the poorest people }\end{array}$ & $\begin{array}{l}\text { Economic, } \\
\text { Development }\end{array}$ & $\begin{array}{l}\text { Investment and } \\
\text { assistance for } \\
\text { development } \\
\text { projects }\end{array}$ \\
\hline OECD & $\begin{array}{l}\text { International } \\
\text { organisation }\end{array}$ & $\begin{array}{l}\text { Promote policies to achieve the } \\
\text { highest sustainable economic } \\
\text { growth and employment }\end{array}$ & $\begin{array}{l}\text { Economic, } \\
\text { regulation }\end{array}$ & $\begin{array}{l}\text { Policy analysis and } \\
\text { recommendations, } \\
\text { decisions, } \\
\text { standards, } \\
\text { guidelines, }\end{array}$ \\
\hline IMF & International Fund & $\begin{array}{l}\text { International monetary } \\
\text { cooperation, exchange stability, } \\
\text { assistance to correct imbalances, } \\
\text { under adequate safeguards }\end{array}$ & Economic, Finance & Conditionality \\
\hline ILO & $\begin{array}{l}\text { U.N. agency } \\
\text { (tripartite: } \\
\text { governments, } \\
\text { workers, employers) }\end{array}$ & $\begin{array}{l}\text { Labour protection, freedom of } \\
\text { association, right of collective } \\
\text { bargaining }\end{array}$ & $\begin{array}{l}\text { Labour law, } \\
\text { industrial relations }\end{array}$ & $\begin{array}{l}\text { Conventions, } \\
\text { standard setting } \\
\text { and supervision, } \\
\text { technical } \\
\text { cooperation and } \\
\text { support }\end{array}$ \\
\hline
\end{tabular}

Besides the organisations' missions and technical knowledge, the emphasis on the above mentioned arguments may vary depending on the emerging demands put forward by the constituencies (the political cycle) and on the effectiveness of recommended measures and policies in addressing past and current problems (the technical cycle). With a view to identify the potential sources of change in the international organisations' attitudes about collective bargaining, we can compare the current situation with the mid-1990s, when the convergence of the political and technical levels on deregulation policies was particularly strong. Has anything changed since then? Should we expect any shift in the stance of international organisations? There at least three facts which are contributing to change the overall perceptions, which pertain to both levels and could support a more balanced orientation.

First, it is quite clear that the de-regulation labour market policies have not fully delivered. The spread of non-standard work as well as the reduction in the levels of employment protection and the retrenchment of the welfare state has led to mixed outcomes. The most relevant downside can be found in the segmentation of the labour market (Barbieri and Cutuli 2016) and in the increase in inequality (Piketty 2017). Second, the financial and economic crisis started in 2008-2009 exposed the shortcomings and weaknesses of the new economic order and dramatically increased the share of those who were losing out, betraying the expectations of increasing standards of living. In addition, the experiences with the austerity policies used to absorb the macroeconomic shocks and imbalances have added further evidence to qualify (and somehow downgrade) the effectiveness of standard neo-liberal prescriptions (Papadakis and Ghellab 2014). Third, the governments found themselves under the pressure of financial markets and, in the European Union, of fiscal and budgetary discipline, while at the same time the demands for more protection increased. The combination of the accumulation of evidence about the drawbacks of market enhancing policies at 
the technical level as well as the growing demands for protection at the political level provide a quite distinct environment for the international organisations compared to the 1990s and it could effectively support a revision of the stance about the role of industrial relations and collective bargaining.

In order to assess whether and to what extent this has happened, so far, the next section provides a brief account of the position of international organisations, as it emerges from recent publications and policy reviews. It mainly focuses on technical advice and assistance, rather than on the political dimension, as indicated above. This is because the technical level is involved in analyses aimed to assess and recommend policies and, therefore, it can exert a more direct impact on the national authorities. The political level is particularly important to understand the changes in priorities and perspectives, but the potential impact of international organisations mostly derives from the actions taken at the technical level (Peters and Peter 2012).

\section{International organisations and the regulation of employment}

Trying to depict and characterise the missions and instruments of international organisations is challenging and requires a significant degree of simplification. However, we want to highlight two things. First, we cannot expect to find unitary positions nor trends across different international organisations, even those which are more strictly engaged with economic and employment issues, because they have different missions and they focus on distinct issues. Second, among the international organisations considered here, economic expert knowledge is prevalent, but sectional and rather narrow approaches prevail. Therefore, the treatment of the issue of collective bargaining is often cursory and incidental and mostly reflects standard mainstream economics. Indeed, reference to collective bargaining may be just episodical rather than systematic. As a general and very simple test, we have verified whether any mention of collective bargaining has been included in the last three years of the main flagship reports of the organisations under review here. As Table 2 shows, this happened only in a very small number of cases. The OECD, ILO and the European Commission, among the bodies selected for our analysis, devote systematic attention to collective bargaining. This is not to say that the programmes and actions of the other selected organisations are not important for industrial relations and collective bargaining. Actually, the opposite is true, as we can see form the following examples. However, the limited presence of references to collective bargaining reduces the capacity to identify trends of carry out specific analysis and our discussion must be limited to the documents where such reference can be found and it is more meaningful. 
Table 2. Collective bargaining in the flagship reports of international organisations 2015-2018

\begin{tabular}{|c|c|c|c|}
\hline Organisation & Flagship report & Relevance of collective bargaining & Notes \\
\hline World Trade Organization & World Trade Report & $\begin{array}{l}\text { Trivial. Collective bargaining } \\
\text { mentioned once (2017) }\end{array}$ & No significant elements \\
\hline World Bank Group* & $\begin{array}{l}\text { World Development } \\
\text { Report }\end{array}$ & $\begin{array}{l}\text { Marginal. Some references ( } 2017 \text {, } \\
2018,2019) \text {, but without emphasis } \\
\text { on its potential or actual role }\end{array}$ & $\begin{array}{l}\text { The relevance of trade union representation and } \\
\text { collective bargaining is considered as declining and of } \\
\text { lesser significance for developing countries (2019). The } \\
\text { impact of teachers' unions on student learning is } \\
\text { regarded as indeterminate: it can be positive or } \\
\text { negative depending on local circumstances (2018) }\end{array}$ \\
\hline UNCTAD & $\begin{array}{l}\text { Trade and } \\
\text { Development Report }\end{array}$ & $\begin{array}{l}\text { Limited. Important recognition of } \\
\text { the potential role of collective } \\
\text { bargaining }(2015,2017) \text {, but } \\
\text { without specific policy implications }\end{array}$ & $\begin{array}{l}\text { Recognition of the role that collective bargaining can } \\
\text { play in supporting growth through the contribution to } \\
\text { aggregate demand (2015) as well as of high wages in } \\
\text { containing inequality and promote investment and } \\
\text { productivity (2017) }\end{array}$ \\
\hline IMF & $\begin{array}{l}\text { World Economic } \\
\text { Outlook }\end{array}$ & $\begin{array}{l}\text { Medium. Occasional reference } \\
\text { (2016), but no systematic } \\
\text { consideration }\end{array}$ & $\begin{array}{l}\text { The capacity of collective bargaining to sustain high } \\
\text { and stable employment is recognised, but it depends } \\
\text { on the structure (centralisation or decentralisation), } \\
\text { the presence of flexibility (opening clauses), the design } \\
\text { of extension mechanisms (based on representativeness } \\
\text { and public interest), and coordination (in high trust } \\
\text { environments) (2016, April) }\end{array}$ \\
\hline OECD & Employment Outlook & Extensive (2015-2018) & $\begin{array}{l}\text { Various editions underline the links between collective } \\
\text { bargaining and less inequality (2015), higher skill } \\
\text { proficiency and utilisation (2016), stronger } \\
\text { commitment at the workplace (2016), better } \\
\text { adaptation to local situations, so that relaxing dismissal } \\
\text { regulations would not involve a loss in employment } \\
\text { levels (2016). In-depth analysis of collective bargaining } \\
\text { systems and they role is also included (2017, 2018) }\end{array}$ \\
\hline ILO & $\begin{array}{l}\text { World Employment } \\
\text { Social Outlook } \\
\text { Global Wage Report* }\end{array}$ & Extensive (2014-2018) & $\begin{array}{l}\text { Access to collective bargaining is regarded as basic } \\
\text { labour right per se and contributing to a number of } \\
\text { positive results, including growth, equality (reinforced } \\
\text { by extension mechanisms), democratisation and } \\
\text { participation at the workplace, productivity growth, } \\
\text { reducing the gender pay gap. }\end{array}$ \\
\hline European Commission & $\begin{array}{l}\text { Employment and } \\
\text { Social development } \\
\text { in Europe } \\
\text { Quarterly Report on } \\
\text { the Euro Area }\end{array}$ & Extensive (2015-2018) & $\begin{array}{l}\text { Collective bargaining is seen as contributing to } \\
\text { sustainable and inclusive recovery (ESDE 2015), } \\
\text { reducing wage dispersion and ensuring resilience } \\
\text { through crisis. Social dialogue is considered having a } \\
\text { "key role to play in tackling the challenges related to } \\
\text { labour market and social developments and is a core } \\
\text { component of a well-functioning social market } \\
\text { economy" (ESDE 2016, p. 189). At company level, it can } \\
\text { help achieve mutual gains. Lately, similar positions } \\
\text { were expressed in the Quarterly Report on the Euro } \\
\text { Area prepared by DG ECFIN (2018, 17(3)) }\end{array}$ \\
\hline
\end{tabular}

* 2016-2019

\subsection{The WTO: Specialisation and 'division of labour'}

In the field of global trade, it is well-known and debated that trade agreements can and do have an important impact on labour relations and they may allow different types of social dumping as well as forms of administrative barriers to competition. It is also discussed how social clauses in trade agreements may in fact turn into a key protection instrument for labour in a globalised economy, where the reach of national legislation may be diminished (Agustí-Panareda et al. 2014, ILO 2015, Mückenberger 2015). The WTO does not engage directly with this issue though. It would be important and possible to analyse how the rules set within the WTO and their enforcement through the adjudication processes impact on labour and collective bargaining, but this goes beyond our purposes. Here, it can suffice to mention that the problem of the link between trade and labour 
standards has been raised within the WTO, especially in the mid of the 1990s, but the answer has been to recognise the ILO as the forum to discuss labour standards whereas WTO would be concerned with the support of trade liberalisation. The ministerial declaration adopted on 13 December 1996 at the Singapore WTO biennial meeting states in fact that:

We renew our commitment to the observance of internationally recognized core labour standards. The International Labour Organization (ILO) is the competent body to set and deal with these standards, and we affirm our support for its work in promoting them. We believe that economic growth and development fostered by increased trade and further trade liberalization contribute to the promotion of these standards. We reject the use of labour standards for protectionist purposes, and agree that the comparative advantage of countries, particularly low-wage developing countries, must in no way be put into question. In this regard, we note that the WTO and ILO Secretariats will continue their existing collaboration (paragraph 4 on core labour standards).

In the same line of reasoning, at the end of that decade, the Director-General of the WTO, Mr. Mike Moore, addressed the International Confederation of Free Trade Unions (ICFTU) conference on "Globalisation and Workers' Rights" in Seattle by stating that "I have never seen a contradiction between trade and labour because I don't believe one exists. Open economies, imperfect as they are have delivered more jobs, opportunities and security to more people than alternatives. Countries that have embraced openness and freedom have increased the real incomes of their workers, which in turn has raised labour standards and reduced poverty. Countries that remain closed, remain poorer, underdeveloped, cut off from the world of rights and freedoms".

With this 'division of labour', there are no particular signs that this attitude has change thereafter. Even in the joint WTO-ILO publication on Making Globalisation Socially Sustainable there is no specific focus on industrial relations and collective bargaining and the analysis mostly concentrates on the impact of globalisation on employment, economic volatility and inequality using a standard economic framework. Policy responses are mainly devoted to the design of social protection, welfare provision and education policies (Bacchetta and Jansen 2011).

\subsection{The World Bank: No specific focus on collective representation and bargaining}

The key international organisation for development, the World Bank, considers work and employment from a number of points of view and it is certainly committed to promote the creation of more jobs and to the improvement in working conditions as a fundamental component of economic and social development. One of its flagship report, the just published World Development Report 2019 (World Bank 2019), is dedicated to The Changing Nature of Work and covers how governments can act to address the changes which are transforming employment through technological change and the global competitive environment by investing in social capital and creating an effective system of social security. In particular, the report advances the view that there is the need for a new social contract, a new deal for the 21st century.

The report is complex, detailed, well-written and well-argued. But the collective dimension of the regulation of labour is rather narrow and the role of collective bargaining and industrial relations is underdeveloped. The basic assumption and conclusion is that public intervention should focus on promoting investment in human capital and providing appropriate and inclusive social protection. "When social protection is established, flexible labor regulation eases work transitions" (World Bank 2019, p. 10). Labour relations are depicted as practically inviable for developing countries, where informality prevails, and declining in advanced economies. "The current social contract is broken in most emerging economies, and it is looking increasingly out of date in some advanced economies as well. A new social contract should include investing in human capital to generate more opportunities for workers to find better jobs" (ibidem). The recognition that collective representation and bargaining may help address the problems of labour protection in a more 
flexible labour market is accompanied by what seems the acceptance of an inevitable decline. "Moving to a simpler core [employment] contract would require stronger collective bargaining structures as fewer protections are specified in the law. However, the significance of such structures is declining" (p. 118). No specific roles for the trade unions and collective bargaining are envisaged in the new social contract for developing countries in the 21st century.

Similarly, the World Bank Doing Business annual reports include a section on labour market regulation, but it is not currently used to calculate the country ranking, after the original index (Employing Workers Indicator) was criticised for concentrating on employment flexibility and disregarding worker protection (Doing Business Employing Workers Consultative Group 2011). In fact, the original indicator focused on four sub-dimensions: the difficulty of hiring, the rigidity of hours, the difficulty of redundancy and the redundancy cost" (p. 2). The review carried out in 20092011 by an expressly appointed Consultative Group pointed to the importance of integrating the index by considering worker protection and mentioned the fact that "it does not measure aspects of the ILO core labor standards - effective recognition of the right to collective bargaining, the elimination of forced labor, the abolition of child labor and the elimination of discrimination in respect of employment and occupation" (p. 4). The Consultative Group issued some suggestions to amend the indicator and to include the notion of excessive flexibility and excessive rigidity, instead of calculating the costs for enterprises, as in the overall approach of the Doing Business methodology. The report led to a revision of the labour market indicators, which currently include some standard measures of employment protection legislation, such as the regulation of fixed-term contracts and dismissal procedures, the regulation of working hours, and certain indicators covering wages, premiums and annual leave. Job quality is taken into consideration through the attention to equality, maternity leave, sick leave, and unemployment protection. No reference to collective representation and collective bargaining is included.

In this perspective, a recent review of labour market reforms prepared in connection with the Doing Business 2018: Reforming to Create Jobs (Kuddo 2018) recognises that "there is no overall blueprint to design or adapt labor regulations. Rather, there are different reform paths that depend on country characteristics shaped by social, political, economic, and historical circumstances, combined with different legal traditions" (p. 57). However, the text tends to reflect a pro-flexibility standard economic perspective, as it affirms that "by discouraging firing, employment regulations may slow down adjustment to shocks and impede reallocation of labor, with potentially negative implications for productivity growth and adaptation to technological change" (p. 58). According to the paper, "enterprise restrictions on terminations in many countries are considerable" and "countries should consider eliminating or limiting some of these restrictions. Such reform would give employers greater flexibility in responding to market fluctuations through their workforce. If not, employers will be reluctant to hire workers, and more inclined to operate in the informal sector" (pp. 58-59). As mentioned above, this kind of publication (a Jobs Working Paper) does not reflect the position of the World Bank, and the usual disclaimer apply. However, it provides an indication of the overall debate, in connection with the preparation of one of its fundamental publications.

\subsection{UNCTAD: Collective bargaining as a catalyst for recovery}

The role and the assessment of the impact of collective bargaining may change if the focus shifts from the micro-level analysis of allocative efficiency in the labour market to the macro-level effects of wage dynamics on growth and employment. A policy brief issued by UNCTAD in 2012, based on the World Development Report of that year, stresses the importance of wages and of a greater income share for labour as a "catalyst for global economic recovery and employment". The policy 
brief indicates as a principle for the action of governments that "average nominal wages rise at the same rate as average productivity plus the inflation target" and "collective bargaining mechanisms can contribute to achieving this" (p. 4). However, due to the mission and operations of UNCTAD, there are no systematic follow-ups in the reports of the subsequent years, especially in terms of policy recommendations. Table 2 shows that the role of wage setting in supporting economic growth has remained part of the arguments put forward by UNCTAD (Trade and Development Report 2015, 2017). This represents an important recognition, but it remained without specific elaborations, as far as it can be seen from the main analyses and reports scrutinised here.

\subsection{IMF and OECD: From the macro to the micro}

The distinction between the micro- and the macro-level of the analysis can be insightful and relevant also when considering the positions of the international organisations which drew the attention of industrial relations practitioners and scholars in the first place, that is OECD and IMF. It should be recalled, in fact, that economic perspectives at the micro- and macro-level may somehow differ, especially because they stress different problems and processes. What can be seen in some of the latest documents and analyses issued by OECD and IMF can be probably regarded as a more balanced micro-and macro approach, which does not and probably could not abandon the prevailing mainstream economics view, due to their institutional mission and main technical knowledge.

We can briefly review their positions as included in recent documents. IMF offers a broad range of documents to support our assessment, since we can compare the statements in their flagship reports, policy papers and country reports as well as the coverage of collective bargaining in the letter of commitment and Memorandum of Understanding accompanying their financial assistance. The various types of documents offer a relatively consistent view of the IMF position over time. As far as wage setting institutions are concerned, according to a recent IMF discussion note (with the usual disclaimer), they should guarantee responsiveness to macroeconomic shocks and productivity developments: "bargaining systems that are more favourable to employment than wage increases should be encouraged and automatic indexation minimized. Minimum wages need careful calibration to productivity realities" (Barkbu et al. 2012, p. 21). If we turn to the IMF flagship World Economic Outlook, in the April 2003 issue there is the recognition that bargaining coordination can produce different results, depending on the impact of wage developments. If it hinders wage adjustments to economic and labour market conditions, it can lead to persistent unemployment, whereas it can have a positive impact, if it increases the capacity to control inflation and the responsiveness to competitiveness issues. Therefore, wage coordination has positive impacts as long as it amounts to wage moderation - especially if monetary policy is in the hands of a credible independent central bank (IMF 2003, p. 138). In the April issue of the 2016 World Economic Outlook, specific attention is devoted to reforms of collective bargaining that can deliver high and stable employment. In particular, the IMF intends to analyse the "macroeconomic performance of collective-bargaining systems as a key tool to strengthen the responsiveness of wages and working hours to macroeconomic shocks and, ultimately, to help achieve high and stable employment" (IMF 2016, p. 131-133). One important feature to achieve these goals is "flexibility at the firm level to accommodate temporary shocks", like hardship and opening clauses - as opposed to the favourability principle. Flexibility should be well calibrated to avoid adverse effects as increasing inequality. Extension mechanism may be important to reduce inequality and avoid competition on poor working conditions, but should be linked to representativeness criteria or public interest clauses and allow exemptions. Coordination is also important and can improve economic performance, especially in high trust environments. In a more traditional line of argument, recent country recommendations insist on the necessity of ensuring alignment with productivity levels and 
differentials across sectors and regions (IMF 2018 on Spain) and advocate decentralisation at the company level, including on ground of the alleged limited effectiveness of attempted organised decentralisation (IMF 2017 on Italy). Indeed, the 2016 openings of the IMF towards collective bargaining stand out so far as an exception, rather than a novel stance.

Of the international organisations under review here, the OECD is probably the most focused on policy analyses and recommendations. Although it also covers activities such as promoting international agreements and standards, it is mostly regarded as a source of data, analyses and evidence-based reviews aimed to promote effective policies in a number of areas, including employment, education, and public administration. Indeed, the 1994 Jobs Study, as stressed above, has been remarkably influential in supporting the flexibilisation of labour markets and the strengthening of active labour market policies. As testimony of its relevance, the prescriptions promoted by the OECD as well as its analysis of regulatory stringency, for instance with the Employment Protection Index have attracted a number of criticism and stimulated further analyses and literature. The review of the Jobs Strategy, in light of the results of past policies and of new emerging issues, has been debated for a number of years, with a first reassessment in 2006 (OECD 2006). The latest revision of the Jobs Strategy has been recently incorporated in a new document at the highest political level (the OECD Council at ministerial level). Considering its prominence, our analysis can focus on this key paper (OECD 2018; see the extensive reviews in this issue). In general, a significant shift in the overall approach is the somehow novel emphasis on the quality of jobs. The main shortcomings of past deregulating policies have been, in fact, the possible segmentation of labour markets, with secondary and marginal segments trapped in low-paid and low-security jobs, and the increase in earning inequality, especially at the expenses of the low end of the pay scale.

As far as collective bargaining is concerned, the main policy recommendations of the new Jobs Strategy include the promotion of the inclusiveness of collective bargaining systems, which should at the same time be sufficiently flexible to accommodate shocks and structural change (OECD 2018, p. 10). The document identifies a possible trade-off between coverage and adaptability, since the first increases as the level of bargaining moves from the workplace to the sectoral or cross-sector levels, whereas the second can diminish (pp. 25-26). According to the OECD, the conditions to ensure inclusiveness are complex and they must preserve the basic economic compatibility. With a view to support inclusive bargaining systems, policies may be designed to promote social dialogue in all types of firms and for all kinds of employment relations. Extension may provide an alternative to the presence of social partners with a broad membership basis, but they should be based on reasonable representativeness or public interest criteria and envisage exemptions and opt-outs. Bargaining systems should be sufficiently flexible to adapt wages and working conditions to difficult economic conditions. This may be achieved through organised decentralisation, supported by diffused workplace representation and wage coordination (pp. 28-29).

Compared to the previous 1994 Job Strategy, the consideration of collective bargaining is much broader and significant. The new document also underlines the benefits that well-functioning industrial relations may bring. On the downside, the new position leaves the impression of a certain degree of 'overspecification' of the basic features that a well-functioning collective bargaining system should show. There is no particular recognition of the autonomous nature of industrial relations and it is treated in a rather 'functionalistic' manner. Probably due to the OECD mission, the role of trade union representation and collective bargaining is recognised as long as it supports the performance of the overall economy, with no consideration of the underlying conflicts that may characterise the employment relations. At the same time, the new 2018 Jobs Startegy certainly provides a new and much broader benchmark which can support and legitimise policy measures and claims to support industrial relations systems. 


\subsection{ILO: Collective bargaining as a goal, not a means}

When looking at these outcome-oriented recommendations, the contrast could not be more striking with the ILO. The ILO mission is "promoting social justice and internationally recognized human and labour rights" and it uses a number of tools to do so, working with governments, employers and workers representative. Its basic technical knowledge is rooted in labour law and social protection as well as in industrial relations. One of its strategic objectives is actually strengthening tripartism and social dialogue. The focus is therefore mainly on the input and process phases: voice, representation, participation and joint regulation are at the heart of the ILO approach.

The ILO perspective has been recently re-asserted in the report Work for a Brighter Future prepared by the Global Commission on the Future of Work (2019). This is a programmatic and political document, drafted by a special commission set up at the highest level to celebrate 100 years from the establishment of the ILO, with the participation of political leaders, international organisation officers, trade unionists, employers, NGO representatives and academics. It calls for investment in the institutions of work, including "ensuring collective representation of workers and employers through social dialogue as a public good, actively promoted through public policies" and states that "all workers and employers must enjoy freedom of association and the right to collective bargaining, with the State as the guarantor of those rights" (p. 12). It builds on the premises that "social dialogue and collective bargaining play a key role in building resilience and in adaptation" (p. 33) and that "collective bargaining is a fundamental right and a powerful tool for economic success and social equity, not least in times of transformational change" (p. 42).

The recognition and the promotion of the role of worker representation and collective bargaining can be found in all positions and documents produced by the ILO. References in the flagship reports is common, but it is mainly in the documents which focus specifically on the role of collective bargaining that it is possible to find the most detailed analyses. One recent example focuses on an important institutional feature of collective bargaining systems, that we encountered in some of the analysis of other international organisations: extension mechanisms (Hayter and Visser 2018). The book is aimed at policy makers and social partners and considers extension as a "particular form of regulation that has a proven track record in reducing inequality and, facilitating inclusion in labour markets and addressing the downside of unfair competition" (p. 26). Extension mechanisms also show adaptability and the capacity to respond to changing circumstances (p. 27). According to the authors, administrative extension continues to represent a useful regulatory tool, undergoing renewal, despite the criticism of neoclassical economic views.

\subsection{The European Commission: A political actor}

The European Commission (EC) is a particular case in this review, because contrary to most of the other organisations, which tend to be single-issue agencies, the EC is committed to both economic integration and social-cohesion, since the principle of social dialogue is enshrined in the Treaties. In addition, and more importantly, the European Commission is not a technical body set up to achieve certain goals. It is a relevant part of a full-fledge, although peculiar, political entity. Certainly, it includes a technical infrastructure, as national polities do, but it cannot be analysed nor compared to the international organisations under review here.

During the recent economic crisis, the EC has been criticised for threatening the autonomy of industrial relations and collective bargaining and putting pressure on established national bargaining systems (Marginson 2014; Van Gyes and Schulten 2015). This has been linked to the strengthening of fiscal and budgetary discipline, which was included in the revision of the European economic governance in the early 2010s (the Six Pack, the Two Pack, and the Treaty on Stability, 
Coordination and Governance in the Economic and Monetary Union as well as the Euro Plus Pact) and led to the implementation of the policy coordination cycle of the European Semester. In particular, the EU policy recommendations on wage bargaining (Clauwaert 2016) have been criticised for supporting a 'disorganised decentralisation' (Traxler 1995), wage erosion and increased inequality, without due consideration of existing industrial relations systems.

Lately, the initiatives on the new start for social dialogue (2015) and the European Pillar of Social Rights (2017), taken by the European Commission and sanctioned at the highest political level in the Council and Parliament, seem to point to a change in approach and perspective over industrial relations and collective bargaining. However, if we use the framework applied above, we cannot draw any clear-cut conclusion. At the technical level, the EC combines different competencies and knowledge and focuses on both economic efficiency and the establishment and protection of rights, including in the field of employment relations. The varying knowledge bases and specific responsibilities of the Directorates-General can support differing views. Among the DirectoratesGeneral that are mostly involved in economic and employment issues, the DG for Economic and Financial Affairs focuses on policies aimed to ensure growth, financial stability and employment creation. As the international organisation covering economic issues, in the recent past, it paid less attention to collective bargaining and tended to underline the importance of flexibility in wage setting institutions, according to mainstream economics. The DG for Employment, Social Affairs and Inclusion, on the other hand, has been committed to expand and protect social dialogue. The publication series Industrial Relations in Europe, between 2000 and 2014, has consistently presented and analysed the features of European industrial relations systems and their contribution to a number of policy goals and outcomes.

Having said that, such a sectional image may be at least partly misleading. On one side, the DG for Employment, Social Affairs and Inclusion develops its own economic analyses, which include an assessment of the role and impact of collective bargaining from an economic perspective, as in the Annual Reviews of Labour Market and Wage Developments in Europe. On the other, the DG for Economic and Financial Affairs has lately incorporated a closer focus on collective bargaining and considered specifically the impact of collective bargaining on wage outcomes (DG ECFIN 2018, p. 20-22). The positive role that collective bargaining can play is recognised, although no specific recommendations are put forward. In terms of the collective bargaining structure, the report affirms that "more effective coordination between social partners helps achieving macroeconomic goals such as increasing resilience, stabilising inflation, tackling unemployment, and correcting external imbalances" (p. 21). Similarly, "well-functioning collective bargaining systems also play an important role in mitigating inequality, and ensuring that the benefits from productivity growth are shared fairly", while "a stable industrial relations environment plays an important role in delivering the trust that is needed to adopt, both in good and in bad times, innovative bargaining solutions with the support of the social partners" (p. 22). Whether this is a change in perspective or an episodical recognition, as in the IMF case illustrated above, it is not possible to say. Actually, it may respond to new and emerging political priorities.

Indeed, at the political level, the scope of decision- and policy-making is incommensurably broader in the European Union compared to the 'standard' international organisations, although it must conform to the Treaties and respect the intergovernmental dimension of the most important decision-making processes. This political character is particularly important because it reverses the balance between the political and the technical levels and changes the logic of legitimation. Within international organisations, the narrower scope of their goals, (almost) definitely established in the instituting conventions and agreements, together with the presence of a specific bureaucracy in charge of their implementation often set the balance of power in favour of the technical staff. 
Similarly, whereas international organisations are expected to act neutrally and they derive their legitimation from their technical knowledge, the European Commission and the European Union as a whole enjoy a direct and indirect political legitimation, which provides for considerable scope of action and the clear prominence of the political level.

The framework set by the treaties fully recognises the role of social dialogue and the European Commission is committed to implement it, for instance through the system of the European Sectoral Social Dialogue and in all initiatives in in the social policy field (art. 154 TFEU). In this general and favourable framework, the steps taken to relaunch social dialogue and establish a European Pillar of Social Rights indicate the persistent commitment in that direction. The other side of the coin of the political nature of the European Union is that the prospects of collective employment relations have to be built within the EU polity and cannot be taken for granted. This is in marked contrast with many single-issue and mostly technical international organisations, whose institutional missions and technical knowledge promote stability, as shown by this analysis.

\section{Concluding remarks}

To sum up, it is possible to say that no fundamental paradigm change is seemingly on sight as regards the position of the main international organisations covering economic and employment issues on collective bargaining. Their missions and expert knowledge establish a framework which is difficult to disarticulate. However, something is changing, as the views seem more balanced than in the heyday of deregulation policies in the 1990s, especially if we look at the position of the OECD and the cooperation which involves the ILO in a broader network among the more economicsfocused organisations.

Table 3. What kind of collective bargaining for what?

\begin{tabular}{|l|l|l|l|l|}
\hline Organisation & Main assessment criteria & $\begin{array}{l}\text { Collective bargaining } \\
\text { structure }\end{array}$ & $\begin{array}{l}\text { Institutional features: } \\
\text { Extension }\end{array}$ & Content: Wage setting \\
\hline OECD & $\begin{array}{l}\text { Economic performance: } \\
\text { employment levels, } \\
\text { economic growth, } \\
\text { capacity to reduce } \\
\text { inequalities and risk of } \\
\text { poverty }\end{array}$ & $\begin{array}{l}\text { Coordinated with } \\
\text { flexibility to adapt to local } \\
\text { labour market and } \\
\text { company economic } \\
\text { situation }\end{array}$ & $\begin{array}{l}\text { Extension mechanisms } \\
\text { subject to } \\
\text { representativeness and } \\
\text { public interest checks }\end{array}$ & $\begin{array}{l}\text { Wage developments in } \\
\text { line with productivity }\end{array}$ \\
\hline ILO & $\begin{array}{l}\text { Enforcement of labour } \\
\text { rights and economic } \\
\text { outcomes, especially } \\
\text { reduced inequality and } \\
\text { fair pay and working } \\
\text { conditions }\end{array}$ & $\begin{array}{l}\text { Inclusive collective } \\
\text { bargaining: coordinated } \\
\text { multi-employer } \\
\text { bargaining }\end{array}$ & $\begin{array}{l}\text { Extension mechanism } \\
\text { adaptable to local } \\
\text { circumstances }\end{array}$ & $\begin{array}{l}\text { Fair wage and } \\
\text { containment of inequality }\end{array}$ \\
\hline European Commission & $\begin{array}{l}\text { Economic performance } \\
\text { and enforcement of } \\
\text { labour rights }\end{array}$ & $\begin{array}{l}\text { Coordinated multi- } \\
\text { employer agreements } \\
\text { with local flexibility }\end{array}$ & $\begin{array}{l}\text { Extension mechanisms } \\
\text { with transparent criteria, } \\
\text { including for exemptions }\end{array}$ & $\begin{array}{l}\text { Wage developments in } \\
\text { line with productivity }\end{array}$ \\
\hline
\end{tabular}

* 2016-2019

Table 3 summarises the idea of collective bargaining that is present in the latest contributions of OECD, ILO and the European Commission, there a number of commonalities, but differences persist, especially in terms of the potential trade-off between the efficiency- and equality-enhancing character of the wage-setting role of collective bargaining. However, distances are probably narrower now than two decades ago. The more balanced emerging view reflects the experience with more than two decades of deregulating labour markets, which did not fully deliver the expected results and the (re-)emerging awareness about the problem of inequality and its consequences on both living standards and the prospects of economic growth, through the negative impact on aggregate demand. In addition, the benefits of coordinated wage bargaining for 
macroeconomic stability, in a period of financial instability, has become more apparent. These two elements have promoted the revival of some insights of traditional Keynesian demand-side economics and of the neo-corporatist literature. As for the political side, the change in the political climate, fostered by the economic difficulties and ailing economic growth in many countries, is pushing towards some more nation-centred initiatives, which may involve the scaling back of economic integration and labour market deregulation. The new situation therefore represents a challenge: it contains the recognition of the role of industrial relations and collective bargaining and it acknowledges the possible shortcomings of market deregulation, but it may foster a conservative turn which may involve the compression of the autonomy of the joint regulation of labour as well as of the progressive role that the representation of labour has played historically. Eventually, finding the responses is the joint responsibility of social and political actors, hopefully with a little help from the international organisations.

\section{References}

Agustí-Panareda, J., Ebert, F.C., LeClercq, D. (2014), Labour Provisions in Free Trade Agreements: Fostering their Consistency with the ILO Standards System, Background Paper - Social Dimensions of Free Trade Agreements, Geneva: ILO.

Baccaro, L., Howell, C. (2017), Trajectories of Neoliberal Transformation. European Industrial Relations Since the 1970s, Cambridge: Cambridge University Press.

Bacchetta, M., Jansen, M. (2011), editors, Making Globalization Socially Sustainable, Geneva: International Labour Organization Publications and World Trade Organization Publications.

Barbieri, P. Cutuli, G. (2016), Employment Protection Legislation, Labour Market Dualism, and Inequality in Europe, in European Sociological Review, vol. 32, no. 4, pp. 501-516.

Barkbu, B., Rahman, J., Valdés, R., and a staff team (2012), Fostering Growth in Europe Now, IMF Staff Discussion Note, SDN 12/07.

Clauwaert, S. (2016), The country-specific recommendations (CSRs) in the social field. An overview and comparison. Update including the CSRs 2016-2017, Background analysis 2016.01, ETUI.

Coleman, J.S. (1990), Foundations of Social Theory, Cambridge, Mass.: Harvard University Press.

Dellmuth, L.M., Tallberg, J. (2015), The social legitimacy of international organisations: Interest representation, institutional performance, and confidence extrapolation in the United Nations, in Review of International Studies, vol. 41, pp. 451-475.

Directorate-General for Economic and Financial Affairs, DG ECFIN (2018), Quarterly Report on the Euro Area, vol. 17, no. 3, European Economy, Institutional Paper 093.

Dore, R. (2004), New forms and meanings of work in an increasingly globalized world, Geneva: ILO.

Dore, R. (2008), Financialization of the global economy, in Industrial and Corporate Change, Vol. 17, No. 6, pp. 1097-1112.

Dunlop, J.T. (1993), Industrial Relations Systems, Boston, Mass.: Harvard Business School Press. Global Commission on the Future of Work (2019), Work for a brighter future, Geneva: ILO. Hayter, S., Visser, J. (2018), editors, Collective Agreements: Extending Labour Protection, Geneva: ILO:

Held, D., McGrew, A. (2002), Governing Globalization: Power, Authority, and Global Governance, Cambridge: Polity Press. 
ILO (2015), Social Dimensions of Free Trade Agreements, Geneva: ILO.

IMF (2003), World Economic Outlook. Growth and Institutions. April 2003, Washington, D.C.: IMF. IMF (2016), World Economic Outlook. Too Slow for Too Long. April 2016, Washington, D.C.: IMF. IMF (2017), Italy. 2017 Article IV Consultation, IMF Country Report No. 17/237, Washington, D.C.: IMF.

IMF (2018), Spain. 2017 Article IV Consultation, IMF Country Report IMF Country Report No. 18/330, Washington, D.C.: IMF.

Joachim, J., Reinalda, B., Verbeek, B. (2008), editors, International Organizations and Implementation. Enforcers, Managers, Authorities?, London: Routledge.

Kuddo, A. (2018), Labor Regulations throughout the World: An Overview, Jobs Working Paper, Issue No. 16, World Bank.

Lovoie, M., Stockhammer, E. (2012), Wage-led growth: concept, theories and policies, in Conditions of Work and Employment Series, no. 41, International Labour Office.

Marginson, P. (2015), Coordinated bargaining in Europe: From incremental corrosion to frontal assault?, in European Journal of Industrial Relations, vol. 21, no. 2, pp 97-114.

Martin, L., Simmons, B.A. (2012), International Organizations and Institutions, in W. Carlsnaes, T. Risse and B.A. Simmons, Handbook of International Relations. Second edition, Thousand Oaks, CA: SAGE Publishing, pp. 326-351.

Mückenberger, U. (2015), Can International Investment Agreements Support Labour Standards?, in S. Vitols (editors), Long-term Investment and the Sustainable Company: A Stakeholder Perspective, vol. III, Brussels: ETUI, pp. 177-205.

Muldoon, J.P. Jr. (2004), The architecture of global governance. An introduction to the study of international organizations, New York-London: Taylor \& Francis.

Ness, G.D., Brechin, S.R. (1988), Bridging the Gap: International Organizations as Organizations, in International Organization, vol. 42, no. 2 (spring), pp. 245-273.

OECD (1994), The OECD Jobs Study. Facts, Analysis, Strategies, Paris: OECD.

OECD (2018), Good Jobs for All in a Changing World of Work: The OECD Jobs Strategy, Paris: OECD. Papadakis, K., Ghellab, Y. (2014), editors, The governance of policy reforms in southern Europe and Ireland. Social dialogue actors and institutions in times of crisis, Geneva: ILO.

Peters, A., Peter, S. (2012), International Organizations: Between Technocracy and Democracy, in B. Fassbender and A. Peters, The Oxford Handbook of the History of International Law, Oxford: Oxford University Press, pp. 170-197.

Piketty, T. (2017), Capital in the Twenty-First Century, Cambridge, Mass.: The Belknap Press of Harvard University Press.

Reinalda, B. (2001), Decision Making within International Organizations. An Overview of Approaches and Case Studies, paper for delivery at the European Consortium for Political Research (ECPR), 29th Joint Sessions of Workshops, Grenoble, France, 6-11 April 2001.

Streeck, W. (1997), Beneficial Constraints: On the Economic Limits of Rational Voluntarism, in J. Hollingsworth and R. Boyer (eds.), Contemporary Capitalism: The Embeddedness of Institutions Cambridge: Cambridge University Press, pp. 197-219. 
Traxler F. (1995), Farewell to Labour Market Associations? Organized versus Disorganized Decentralisation as a Map for Industrial Relations, in C. Crouch and F. Traxler, editors, Organised Industrial Relations in Europe: What Future?, Aldershot: Avebury, pp. 3-19.

Traxler, F., Kittel, B, S. Lengauer (1997), Globalisation, collective bargaining and performance, in Transfer: European Review of Labour and Research, vol. 3, no. 3, pp. 787-806.

UNCTAD (2012), Greater income share for labour - The essential catalyst for global economic recovery and employment, Policy Brief, No. 26, December.

Van Gyes, G., Schulten, T. (2015), editors, Wage bargaining under the new European Economic Governance. Alternative strategies for inclusive growth, Brussels: ETUI.

World Bank (2019), World development Report 2019, Washington, D.C.: The World Bank Group.

World Bank Doing Business Employing Workers Consultative Group (2011), Final Report, Washington, D.C.: The World Bank Group. 